Citation:

O'Kelly B.C. 2008. Effect of biodegradation on the consolidation properties of a dewatered municipal sewage sludge. Waste Management, Vol. 28, No. 8, 13951405 .

\title{
EFFECT OF BIODEGRADATION ON THE CONSOLIDATION PROPERTIES OF A DEWATERED MUNICIPAL SEWAGE SLUDGE
}

\author{
Brendan C. O'Kelly ${ }^{1}$ \\ Lecturer in Civil Engineering \\ Department of Civil, Structural, and Environmental Engineering \\ Museum Building, Trinity College Dublin, Dublin 2, Ireland
}

First submission: 6th June 2006

Resubmitted_1: 6th March 2007

Resubmitted_2: 10th July 2007

\begin{abstract}
The effect of biodegradation on the consolidation characteristics of an aerobically digested, dewatered municipal sewage sludge was studied. Maintained-load oedometer consolidation tests that included measurement of the pore fluid pressure response were conducted on moderately degraded slurry and saturated bulk samples that had been stored under static conditions and allowed to anaerobically biodegrade (simulating what would happen in an actual sewage sludge monofill or lagoon condition). Strongly degraded material was produced after a storage period of 13 years at ambient temperatures of 5 to $15^{\circ} \mathrm{C}$, with the total volatile solids reducing from initially 70 to $55 \%$.

The sludge materials were highly compressible although impermeable for practical purposes. Primary consolidation generally occurred very slowly, which was attributed to the microstructure of the solid phase, the composition and viscosity of the pore fluid, ongoing biodegradation and the high organic contents. The coefficient of primary consolidation values decreased from initially about $0.35 \mathrm{~m}^{2} /$ year to $0.003-0.03 \mathrm{~m}^{2} /$ year with increasing effective stress $\left(\sigma_{\mathrm{v}}{ }^{\prime}=3-100 \mathrm{kPa}\right)$. Initially, the strongly degraded slurry was slightly more permeable although both materials became impermeable for practical purposes $\left(\mathrm{k}=10^{-9}-10^{-12} \mathrm{~m} / \mathrm{s}\right)$ below about 650 and $450 \%$ water contents, respectively. Secondary compression became more dominant with increasing effective stress with a mean secondary compression index $\left(\mathrm{C}_{\alpha \mathrm{e}}\right)$ value of 0.9 measured for both the moderately and strongly degraded materials.
\end{abstract}

Keywords: biodegradation, compressibility, consolidation, permeability, sewage sludge

\footnotetext{
${ }^{1}$ Email: bokelly@tcd.ie

Tel. +35318962387

Fax. +35316773072
} 


\section{Introduction}

Sewage sludge is the concentrated, bioactive residue of mostly organic clay-sized particles derived from wastewater treatment processes. The consolidation and hydraulic characteristics of the dewatered sludge material are of major importance with regard to its long-term behavior in landfills (sludge monofills, municipal landfills or sludge lagoons), currently the principal means of disposal within the European Community. In many countries, there is almost complete reliance on landfilling since the spreading of the material on land is banned and incineration may not be an option. The sludge landfill and its engineered capping system are subject to considerable settlement that must be assessed at the design stage.

In practice, sewage sludge shows unpredictable consolidation behavior that can be attributed to a number of causes (Klein and Sarsby, 2000). Firstly, the engineering processes for treating and dewatering the raw wastewater generally involve the addition of flocculating agents that affect the final structure of the sludge material. Secondly, ongoing or reactivated biodegradation of the volatile organic solids occurs especially if the material is disturbed, warmed or aerated. Thirdly, the composition and viscosity of the pore fluid (more akin to a soft gel than water) is likely to change with time. The consolidation properties of sewage sludge materials, including dewatered sludge material direct from the treatment plant (Lo et al., 2002); material in a sludge lagoon (Aydilek et al., 2000; Klein and Sarsby, 2000) and dried compacted sludge materials (Lo et al., 2002; Stone et al., 1998) have been studied using the standard oedometer apparatus, the Rowe hydraulic consolidation cell and the flexible wall permeameter. The sewage sludge materials were reported to be highly compressible but were impermeable for practical purposes with the logarithm of the coefficient of permeability decreasing linearly with decreasing void ratio (Lo et al., 2002; Aydilek et al., 2000).

This paper studies the effect of biodegradation on the compressibility, consolidation and permeability characteristics of an aerobically digested, municipal sewage sludge material using oedometer consolidation tests and with measurement of the pore fluid pressure response. The use of the data in predicting the settlement responses of the material at different levels of degradation in an engineered, sewage sludge monofill or lagoon is reported.

\section{Experimental methods}

\subsection{Test materials}

The dewatered sewage sludge material was obtained from Tullamore municipal wastewater treatment plant (County Offaly, Ireland) in 1993. The treatment plant served an urban population of about 12,000 and had no significant industrial wastewater influent. The sludge material had been moderately degraded at $35^{\circ} \mathrm{C}$ (optimum temperature for mesophilic digestion) in a bioreactor at the treatment plant using the anaerobic, activated sludge digestion method (Metcalf and Eddy, 1991). The sludge residue was then chemically conditioned using polyelectrolyte additives (Magnafloc ${ }^{\circledR}$ LT22S manufactured by $\mathrm{Ciba} \AA$ ) and consolidated to about $705 \%$ water content $(12.5 \%$ solids content) using a belt-filter press at the treatment plant. Further dewatering of the sludge material at the treatment plant proved most difficult. In geotechnical literature, the water content $\mathrm{w}$, is defined as the ratio of the mass of the pore fluid to the mass of the solid particles, expressed as a percentage. The water content was determined using the oven-drying method (BS1377a, 1990). The mass of the solid particles in the sludge specimen equals the mass achieved after drying in an oven at a temperature of 
$105 \pm 5^{\circ} \mathrm{C}$ for a period of 24 hours. In wastewater literature, the solids content SC, is defined as the ratio of the mass of the solid particles to the total specimen mass (again expressed as a percentage) and can be related to the water content as follows:

$$
S C=\frac{100}{1+\left(\frac{w}{100}\right)}
$$

The geotechnical properties of dewatered sludge material taken direct from the treatment plant and tested in 1993 have been reported by O'Kelly (2005a, 2005b, 2006). Bulk samples of the sludge material $(\mathrm{w} \cong 705 \%)$ were put aside and allowed to naturally biodegrade over an additional period of 13 years. The sludge material alone was stored outdoors in 70-L plastic drums (filled to capacity) and with seasonal temperatures in the range of 5 to $15^{\circ} \mathrm{C}$. The sludge was stored in a saturated state and allowed to degrade anaerobically under static conditions (no mixing) and without any artificial control over the uniformity of the redox potential. The drums were fitted with covers (although not hermetically sealed) which prevented the ingress of rainfall. The material that was used in the test series was sampled from below the mid-height of the storage drums where the slurry have been degrading anaerobically. The storage condition described simulates what would happen in an actual sewage sludge monofill or lagoon condition. The paper deals in particular the impact of biodegradation on the consolidation properties of the sludge material.

\subsection{Classification tests}

A range of standard classification tests was conducted on the sludge material in accordance with BS1377 (1990a,b). The plasticity characteristics were assessed using the liquid limit test (cone penetrometer method) and the plastic limit test. Slurry material refers to sludge with water contents greater than the liquid limit value. The size distribution and mineralogy of the solid particles were assessed by wet sieve and X-ray diffraction analyses. The specific gravity of solids $\mathrm{G}_{\mathrm{s}}$, was measured using the small pycnometer method using kerosene in place of distilled water as the fluid in the density bottles. The total volatile solids TVS, values were determined by igniting the dry powdered solids in a muffle furnace at $440^{\circ} \mathrm{C}$ in accordance with BS1377 (1990b). TVS is widely used in sludge treatment and management practices as a measure of the organic content and hence a means of characterizing the level of biodegradation achieved. The TVS and $\mathrm{G}_{\mathrm{s}}$ values were periodically measured during the course of the 13-year storage period. The linear shrinkage value was determined as the percentage reduction in the length of a bar of the sludge material that had been oven-dried at a temperature of $105^{\circ} \mathrm{C}$ from the liquid limit condition. The shrinkage limit, defined as the water content value below which the sludge material ceases to shrink, was determined from repeated volumetric measurements of specimens that had been slowly air-dried. The void ratio was calculated as the ratio of the volume of the void space to the volume of the solid particles. The $\mathrm{pH}$ value of the leachate was measured using an electrometric method.

\subsection{Oedometer consolidation tests}

Standard maintained-load oedometer consolidation tests (BS1377, 1990c) were conducted in 1993 on the slurry material obtained direct from the treatment plant (specimen A). A second series of oedometer consolidation tests were conducted on slurry material (specimens B-E) 
that had been stored in bulk containers and allowed to anaerobically biodegrade further over the following 13 year period at ambient temperatures of 5 to $15^{\circ} \mathrm{C}$. Table 3 summarizes some key properties and the conditions under which the different specimens were tested. The initial properties of the sludge in specimens B-E were identical although the material was then tested under different loading and drainage conditions.

An important consideration was the aspect ratio of the test specimens which can influence the consolidation test results. Cooling and Skempton (1941) showed that for specimens 50 to 105 $\mathrm{mm}$ in diameter, and with a maximum height to diameter ratio of 0.4 (as specified by BS1377 (1990c)), the experimental data closely agreed with that predicted from Terzaghi (1943) consolidation theory.

Specimens A to $\mathrm{E}$ had similar effective drainage lengths (longest drainage paths). Specimens $\mathrm{C}$ and $\mathrm{E}$ (76.2-mm in diameter and initially $14.8-\mathrm{mm}$ in height) were allowed to drain from the top end only. The pore pressure response was continuously measured at the bottom end of specimens $\mathrm{C}$ and $\mathrm{E}$ via a porous disc located in the base of the consolidation cup (Fig. 1). Biogas that was been naturally produced by the degradation of the specimens was prevented from entering the hydraulic line to the pore fluid pressure transducer by using a high air-entry porous disc and by saturating the line with oil during setup.

Specimens A, B and D (76.2-mm in diameter and initially 30.0- $\mathrm{mm}$ in height) were allowed to drain to atmosphere from both ends via porous stones although this set up precluded measurement of its pore fluid pressure response. The sets of test specimens were prepared by pressing the freshly remolded slurry into the oedometer consolidation rings using a spatula.

Vertical stresses of up to $100 \mathrm{kPa}$ were applied to the test specimens. In general, each load stage was a minimum of 48 hours duration and the applied stress was doubled in moving from one load stage to the next. The load duration of 48 hours provided good estimates of compressive strain to evaluate the long-term compressibility of the sludge material. In addition, single-increment load tests of nine days duration were conducted on specimens D and E. The uniformity of the consolidation that had been achieved throughout the specimens at the end of the oedometer tests was assessed by comparing the water content values of thin slices taken across the height of the specimens.

\section{Experimental results}

\subsection{Index and physical properties}

The properties of the bioactive, grayish-black slurry material are listed in Tables 1 and 2. Both sludge materials were in the slurry state with low bulk unit weights of about 1.03 tonne $/ \mathrm{m}^{3}$ and a high void ratio value of about 11 . The slurry material tested direct from the treatment plant in 1993 had a liquid limit of 315\%; a plastic limit of 55\%; a plasticity index (difference between the liquid and plastic limit values) of $260 \%$, and was classified according to the Unified Soil Classification System as high plasticity organic clay. About $90 \%$ of the solid particles (comprising mostly organic macromolecules and bacteria) passed the $425-\mu \mathrm{m}$ size sieve. X-ray diffraction analysis indicated that the inorganic clay fraction comprised quartz, calcite and kaolinite. A 33\% linear shrinkage occurred for material that had been oven dried from the liquid limit condition. The volume of the material stopped contracting at $10 \%$ water content (shrinkage limit). 
The sludge materials tested direct from the treatment plant and at the end of the additional 13year storage period had TVS values of 70 and 55\%, respectively, with the reduction in TVS equating to about a one-third reduction in the initial dry solid mass. Hence, only moderate degradation of the sludge material had occurred in the bioreactor at the treatment plant whereas strong degradation had occurred by the end of the additional storage period of 13years. Also, specimens W, X and Y were tested after the material from the treatment plant had been stored under static conditions for periods of 3, 4 and 30 months at ambient temperatures of 5 to $15^{\circ} \mathrm{C}$. The TVS and specific gravity of solids $\left(\mathrm{G}_{\mathrm{s}}=1.55-1.71\right)$ values were found to be inversely related (Fig. 2). This can be explained by ongoing biodegradation which breaks down the volatile organic solids (water, methane and carbon dioxide generated as byproducts), increasing the proportion of denser mineral particles, which in turn increases the specific gravity and the unit weight of the material. Similar values were reported for strongly degraded sewage sludge by Klein and Sarsby (2000) with TVS $=51-55 \%$ and $\mathrm{G}_{\mathrm{s}}=1.74$ 1.77. The rate of reduction in the TVS values and hence the rate of biodegradation became progressively slower for the sludge material (stored under static conditions and allowed to anaerobically degrade at ambient temperatures of 5 to $15^{\circ} \mathrm{C}$ ). Higher levels of degradation can be expeditiously achieved in practice by extending the retention period in the bioreactor at the wastewater treatment plant. For example, comparable levels of biodegradation can be achieved by allowing the material to naturally biodegrade further at ambient temperatures of 5 to $15^{\circ} \mathrm{C}$ over a 13 -year period or by holding the material in the bioreactor at ambient temperature of $35^{\circ} \mathrm{C}$ for an additional period of 21 days (specimen $\mathrm{Z}$ in Fig. 2, O'Kelly (2006)). Hence, higher levels of biodegradation at the wastewater treatment plant can significantly reduce the dry solid mass as well as the associated costs of transporting the bulk material off site for disposal.

\subsection{Consolidation curves}

The oedometer data for the slurry material that had been taken and tested direct from the treatment plant in 1993 (specimen A) are plotted in Fig. 3 as cumulative strains versus logarithm of elapsed time and square-root of elapsed time, as is customary to facilitate standard curve-fitting analyses. Likewise, Fig. 4 shows the oedometer data for the material that had been allowed to naturally biodegraded further over the 13-year storage period (specimens B-E). Figure 5 shows the normalized excess pore fluid pressure responses $\left(\Delta \mathrm{u}_{\mathrm{b}} / \Delta \sigma_{\mathrm{v}}\right.$ in which $\Delta \mathrm{u}_{\mathrm{b}}$ is the excess pore fluid pressure response recorded at the base of the specimen and $\Delta \sigma_{v}$ is the step increase in the applied stress) that were measured for specimens $\mathrm{C}$ and $\mathrm{E}$ that had been set up for one-way drainage conditions. The strain versus time and pore fluid pressure dissipation curves are typical of the consolidation behavior of highly organic clay. Small changes in the ambient laboratory temperature over the duration of the oedometer tests caused small cyclic variations in the transducer base readings which are reflected in the data plots.

Overall, the sludge materials compressed at a fairly steady rate with large specimen strains of about $70 \%$ achieved by the end of the final load stage. The initial specimen compression measured at the start of each load stage was negligible indicating that favorable drainage lengths had allowed the biogas that had been generated during the course of the tests to escape so that the specimens remained in a fully saturated state. Significant initial compressions would have been expected had the bubbles of biogas remained trapped within the pore voids. The marginal differences between the strain responses shown in Fig. 4 for specimens B and C 
(initially identical material properties) can be explained by the slight differences in the rates of secondary compression (due to the different specimen heights) and slightly different initial effective drainage lengths ( 15.0 and $14.8 \mathrm{~mm}$, respectively). The water content tests that were conducted on thin slices of the specimens at the end of the oedometer tests indicated that uniform consolidation had been achieved throughout the specimens.

In general, standard curve-fitting techniques (BS1377, 1990c) could not readily differentiate the contributions in the data curves (Figs. 3 and 4) of primary consolidation and secondary compression. Primary consolidation occurs due to drainage and hence the dissipation of the excess pore fluid pressures. Secondary compression continues indefinitely after the excess pore fluid pressures have largely dissipated. Secondary compression occurs due to the realignment and compression of the solid phase (sludge flocs), and the ongoing biodegradation and hence reduction in the volume of the organic solids.

\subsection{Compressibility}

The applied vertical effective stress-strain-time responses that were measured during the oedometer tests are presented in the form of void ratio versus logarithm of effective stress (e$\left.\log \sigma_{\mathrm{v}}{ }^{\prime}\right)$ plots in Fig. 6. The compressibility of the materials was quantified in terms of the compression index $\mathrm{C}_{\mathrm{c}}$ parameter, defined as the gradient of the e- $\log \sigma_{\mathrm{v}}{ }^{\prime}$ curve. The $\mathrm{C}_{\mathrm{c}}$ values of most natural clays are less than 1.0, and generally less that 0.5 . The sludge materials were highly compressible with the very high $\mathrm{C}_{\mathrm{c}}$ values decreasing in magnitude with increasing effective stress $\left(\sigma_{\mathrm{v}}{ }^{\prime}=6-100 \mathrm{kPa}\right)$ from $\mathrm{C}_{\mathrm{c}}=7.2$ to 4.4 for material that had been tested direct from the treatment plant; and $\mathrm{C}_{\mathrm{c}}=3.7$ to 2.7 when tested after being stored for a period of 13years. The corresponding values of the primary compression ratio $\mathrm{C}_{\mathrm{c}}{ }^{*}(\mathrm{Eq}$. 2) were 0.6 to 0.4 and 0.4 to 0.2 . These values are within the range of $\mathrm{C}_{\mathrm{c}}=10.0$ to 1.5 (Sarsby 2005) and $\mathrm{C}_{\mathrm{c}}{ }^{*}=$ 0.3 and $\mathrm{C}_{\mathrm{c}} *>0.2$ (Lo et al., 2002; Aydilek et al., 2000) reported for other sewage sludge material.

$$
C_{c}^{*}=\frac{C_{c}}{1+e_{o}}
$$

in which $e_{o}$ is the initial void ratio.

\subsection{Consolidation properties}

The relative contribution and rate of primary consolidation were reliably interpreted from analysis of the average degrees of consolidation calculated during the course of the oedometer tests. The average degrees of consolidation shown in Fig. 7 were calculated from the pore fluid pressure responses that had been measured for specimens C and E. Specimens A, B and $\mathrm{D}$ had been set up for two-way drainage conditions which precluded measurement of their pore pressure responses. The distribution of the excess pore pressures over the specimen height is defined by a parabola whose vertex value (equal to the pore fluid pressure measured at the specimen base, $u_{b}$ ) reduces with increasing elapsed time, Fig. 8. At any given time, the average degree of consolidation $\bar{U}$, is calculated as the ratio of the area enclosed by the parabola to the initial area corresponding to the step increase in the applied stress $\left(\Delta \sigma_{v}\right)$, expressed as a percentage: 


$$
\bar{U}=\frac{\Delta \sigma_{v}-2 / 3 u_{b}}{\Delta \sigma_{v}}
$$

Analyses of the average degree of consolidation and the strain versus time curves (Figs. 3, 4 and 7) using the logarithm of time (Casagrande and Fadum, 1940) and square-root of time (Taylor, 1942) curve-fitting techniques indicated that primary consolidation generally constituted only a minor part of the overall strain response. The rates of primary consolidation were quantified in terms of the coefficient of primary consolidation, $c_{v}$. The $c_{v}$ values computed using the logarithm of time and the square-root of time curve-fitting techniques were in good agreement with those values computed from the average degrees of consolidation plots. The $c_{v}$ values were very low and decreased significantly with increasing effective stress, from an initial value of about $0.35 \mathrm{~m}^{2} /$ year $\left(\sigma_{\mathrm{v}}{ }^{\prime}=3 \mathrm{kPa}\right)$ to 0.003 and 0.03 $\mathrm{m}^{2} /$ year $\left(\sigma_{\mathrm{v}}{ }^{\prime}=100 \mathrm{kPa}\right)$ for sludge materials tested direct from the treatment plant and after storage for an additional 13-year period, respectively (Fig. 9). Similar behavior has been reported for other sewage sludge materials, with $c_{\mathrm{v}}=0.1-0.7 \mathrm{~m}^{2} /$ year $\left(\sigma_{\mathrm{v}}{ }^{\prime}=1-5 \mathrm{kPa}\right)$ reducing to $0.075 \mathrm{~m}^{2} /$ year at $\sigma_{\mathrm{v}}{ }^{\prime}=10 \mathrm{kPa}$ (Klein and Sarsby, 2000), and $0.02 \mathrm{~m}^{2} /$ year at $\sigma_{\mathrm{v}}{ }^{\prime}=$ $30 \mathrm{kPa}$ (Sarsby, 2005). The consolidation behavior measured in the oedometer tests was also consistent with the experience of mechanically dewatering the material at the wastewater treatment plant.

The very low rates of primary consolidation are attributed to the microstructure of the solid phase (sludge flocs), the composition and viscosity of the pore fluid, the effects of ongoing biodegradation and the high organic content (TVS $=55-70 \%$ ). During consolidation some interstitial pore fluid (existing as liquid trapped within the floc structure) becomes either free water or surface water (Klein and Sarsby, 2000) thereby continuously providing a source of additional pore fluid that compensates in part for the pore fluid that has already been dissipated. Some form of chemical bonding or biological coagulation also occurs between the pore fluid (more akin to a soft gel than water) and the clay-sized organic solids (Sarsby 2005).

\subsection{Permeability}

The coefficient of permeability $\mathrm{k}$, values for each oedometer load stage were measured indirectly as:

$$
k=m_{v} c_{v} \gamma_{w}
$$

in which $\mathrm{m}_{\mathrm{v}}$ is the coefficient of volume change corresponding to the load stage, and $\gamma_{w}$ is the unit weight of the pore fluid.

The coefficient of permeability values of the sludge material are plotted as a function of the effective stress in Fig. 10. The data are also plotted as functions of some physical properties, namely the water content (w) and the void ratio (e), which can be readily calculated in practice using phase relationships. As expected, the coefficient of permeability values decrease significantly with the reduction in the void ratio. For most soils, the logarithm of $\mathrm{k}$ 
decreases linearly with decreasing void ratio (Lambe and Whitman, 1969). Likewise, the logarithm of $\mathrm{k}$ and the logarithm of effective stress were inversely related. From the lines of best fit (coefficients of determination of 0.58 ), the coefficient of permeability values of the sludge material can be estimated from the state of effective stress $\left(\sigma_{\mathrm{v}}{ }^{\prime}=3-100 \mathrm{kPa}\right)$ or the void ratio:

$$
\begin{array}{r}
\log \mathrm{k}=(0.39 \times \mathrm{e})-12.06 \quad[\mathrm{~m} / \mathrm{s}] \\
\log \mathrm{k}=-\left(1.63 \times \log \sigma_{\mathrm{v}}{ }^{\prime}\right)-7.88[\mathrm{~m} / \mathrm{s}]
\end{array}
$$

The sludge material was impermeable for practical purposes. The coefficient of permeability values were extremely low and decreased significantly with increasing effective stress from about $\mathrm{k}=3 \times 10^{-9}$ to $8 \times 10^{-12} \mathrm{~m} / \mathrm{s}$ for $\sigma_{\mathrm{v}}{ }^{\prime}=3$ to $100 \mathrm{kPa}$. This indicates a low leachate migration rate in landfills. The measured values are consistent with those reported for other sewage sludge materials, namely $\mathrm{k}=1.0 \times 10^{-11} \mathrm{~m} / \mathrm{s}(\mathrm{w}=180 \%)$ by Lo et al. (2002) and $\mathrm{k}=0.8 \times 10^{-9}$ $\mathrm{m} / \mathrm{s}\left(\sigma_{\mathrm{v}}{ }^{\prime}=5 \mathrm{kPa}\right)$ measured directly in a constant-head permeability test by Sarsby (2005).

\subsection{Secondary compression}

Secondary compression was generally dominant over primary consolidation for the sludge material and caused significant long-term settlement, as evident from the large reductions in the void ratio values that occurred under the constant applied effective stress for specimens D and $\mathrm{E}$ (Fig. 6). The rates of secondary compression were quantified in terms of the coefficient of secondary compression $\mathrm{C}_{\mathrm{sec}}$, calculated as the strain response (expressed as a decimal) that occurred over one logarithm of time cycle during the secondary compression phase. Tables 4 and 5 list the $\mathrm{C}_{\mathrm{sec}}$ values calculated from the multiple-increment oedometer data plots (specimens A-C). Similar $\mathrm{C}_{\mathrm{sec}}$ values of 0.12 and $0.075\left(\sigma_{\mathrm{v}}{ }^{\prime}=3\right.$ and $6 \mathrm{kPa}$, respectively) were calculated from the longer-term, single-increment load tests on specimens $\mathrm{D}$ and $\mathrm{E}$. The $\mathrm{C}_{\mathrm{sec}}$ values, although very high in comparison with the values reported for inorganic soils, are consistent with the high TVS values of the sludge material. The sludge material direct from the treatment plant and the material stored over an additional 13-year period both had a mean secondary compression index $\mathrm{C}_{\alpha \mathrm{e}}$ (Eq. 7) value of 0.9. These values are consistent with the $\mathrm{C}_{\alpha \mathrm{e}}$ values computed from the $\mathrm{C}_{\mathrm{sec}}$ data plots reported for other sewage sludges by Klein and Sarsby (2000) and Aydilek et al. (2000).

$$
C_{\alpha e}=C_{s e c}\left(1+e_{o}\right)
$$

The values of the primary compression ratio to secondary compression index $\left(\mathrm{C}_{\alpha e} / \mathrm{C}_{\mathrm{c}}\right.$, introduced by Mesri and co-workers (for example, Mesri et al., 1995) are also listed in Tables 4 and 5. The mean values of the $\mathrm{C}_{\alpha \mathrm{e}} / \mathrm{C}_{\mathrm{c}}$ ratio were 0.2 and 0.3 for sludge material tested direct from the treatment plant and the material stored over an additional 13-year period, respectively. 


\section{Discussion}

\subsection{Effect of biodegradation on the consolidation behavior}

Primary consolidation initially occurred more rapidly for the more strongly degraded material with typical coefficient of permeability values, although still very low, of the order of $10^{-8}$ to $10^{-9} \mathrm{~m} / \mathrm{s}$. For example, a comparison of the strain responses in Fig. 11 indicates that at the end of the first load step $\left(\sigma_{\mathrm{v}}{ }^{\prime}=3 \mathrm{kPa}\right)$, only about $7 \%$ compressive strain had occurred for the material tested direct from the treatment plant (specimen A) compared to about $23 \%$ compressive strain for the material tested after storage for another 13-years (specimens B and C). Almost complete dissipation of the excess pore fluid pressures had also been measured by the end of the 3,6 and $12.5 \mathrm{kPa}$ load stages for the latter material (Fig. 7).

However, primary consolidation occurred progressively slower and secondary compression became more dominant with further increases in the effective stress (evident from the decreasing rates of dissipation of the excess pore fluid pressures for $\sigma_{\mathrm{v}}{ }^{\prime}>12.5 \mathrm{kPa}$ ) with final degrees of consolidation of only 65-70 \% achieved (Fig. 7). The slurry materials tested direct from the treatment plant and at the end of the 13-year storage period were both impermeable for practical purposes below about 650 and $450 \%$ water contents (13 and 18\% solids contents), respectively. Further dewatering of the slurry could have been achieved at the wastewater treatment plant by applying much higher consolidation pressures although this would have necessitated using an hydraulic consolidation press in place of the existing beltfilter press.

\subsection{Settlement of sludge monofills}

The use of the presented data in predicting the settlement response of monofills and lagoons of the sewage sludge at different levels of biodegradation is described. The conditions under which the bulk samples had been stored and allowed to naturally biodegrade simulated what would happen in an actual sludge monofill or lagoon condition. The material was shown to be highly compressible although the rate of settlement was very slow and continued over an indefinite period. The time-dependent settlement comprising the sum of the primary consolidation and the secondary compression components $\left(\Delta \mathrm{H}_{\mathrm{c}}\right.$ and $\Delta \mathrm{H}_{\mathrm{sec}}$, respectively) is calculated using Eqs. (8) and (9). The time period for the completion of the primary consolidation phase $\mathrm{t}_{1}$, can be calculated using Eq. (10).

$$
\begin{gathered}
\Delta H_{c}=H_{o} \frac{C_{c}}{1+e_{o}} \log \frac{\sigma_{v o}{ }^{\prime}+\Delta \sigma_{v}{ }^{\prime}}{\sigma_{v o}{ }^{\prime}} \\
\Delta H_{s e c}=H_{o} C_{s e c} \log \frac{t_{1}}{t_{2}} \\
t_{1}=T_{v} d^{2} / c_{v}
\end{gathered}
$$

in which $\mathrm{d}$ is the longest drainage path,

$\mathrm{H}_{\mathrm{o}}$ is the initial thickness of the sludge deposit,

$\mathrm{T}_{\mathrm{V}}$ is a time factor related to the average degree of consolidation (Terzaghi, 1943),

$t_{2}$ is the time period that extends into the secondary compression phase $\left(t_{2}>t_{1}\right)$,

$\sigma_{\mathrm{vo}}$ ' is the initial vertical effective stress,

and $\Delta \sigma_{\mathrm{v}}{ }^{\prime}$ is the increase in the applied vertical effective stress. 
The values of the compression index (Fig. 6), the coefficient of primary consolidation (Fig. 9) and the coefficient of secondary compression (Tables 4 and 5) that are inputted in Eqs. (8-10) must be consistent with the state of effective stress and the actual levels of bioactivity and biodegradation in-situ. Efficient, well-maintained biogas control and leachate drainage systems must be in place to allow the excess pore fluid and pore gas (generated due to the increase in the applied vertical effective stress and ongoing biodegradation) to readily escape. Otherwise, ongoing biogas production may cause the excess pore fluid pressures to steadily increase, thereby reducing the state of effective stress in the sludge material, which may ultimately lead to swelling and instability of the landfill body. However, this effect was not noticeable during the oedometer tests in which the favorable drainage lengths in the specimens had allowed the biogas to escape so that the specimens had remained in a fully saturated state.

\section{Conclusions}

Oedometer consolidation tests were conducted on dewatered municipal sewage sludge at moderate to strong levels of biodegradation. The conditions under which the bulk sludge samples had been stored and allowed to anaerobically biodegrade simulated what would happen in an actual sewage sludge monofill or lagoon condition. The total volatile solids $($ TVS $=55-70 \%)$ and the specific gravity of solids $\left(\mathrm{G}_{\mathrm{s}}=1.55-1.71\right)$ were inversely related since biodegradation increased the relative proportion of the denser mineral particles in the sludge material.

The sludge was highly compressible (primary compression index $C_{c}$, values of 4.4 to 7.2 and 2.7 to 3.7 for the moderately and strongly degraded materials, respectively) although impermeable for practical purposes. Primary consolidation generally occurred very slowly, which was attributed to the microstructure of the solid phase (sludge flocs); the composition and viscosity of the pore fluid (more akin to a soft gel than water); ongoing biodegradation and the high organic contents. The coefficient of primary consolidation values were very low, decreasing from about $0.35 \mathrm{~m}^{2} /$ year initially to only $0.003-0.03 \mathrm{~m}^{2} /$ year with increasing effective stress $\left(\sigma_{\mathrm{v}}{ }^{\prime}=3-100 \mathrm{kPa}\right)$.

The strongly degraded slurry was slightly more permeable (typical coefficient of permeability values of $10^{-8}$ to $10^{-9} \mathrm{~m} / \mathrm{s}$ ) than the moderately degraded material although both materials became impermeable for practical purposes with increasing effective stress $\left(\mathrm{k}=10^{-9}-10^{-12}\right.$ $\mathrm{m} / \mathrm{s}$ for $\mathrm{w}<650$ and $450 \%$, respectively). The logarithm of the coefficient of permeability was directly related to the void ratio and inversely related to the logarithm of the applied effective stress.

Secondary compression became more dominant with increasing effective stress with a mean secondary compression index $\mathrm{C}_{\alpha \mathrm{e}}$, value of 0.9 , irrespective of the level of biodegradation of the sludge material tested. The mean value of the $C_{\alpha e} / C_{c}$ ratio was 0.2 and 0.3 for the moderately and strongly degraded materials, respectively

\section{Acknowledgements}

The author would like to kindly thank Paul Johnston for his helpful comments during the preparation of this paper and Martin Carney and Emma Quinn for performing some of the 
tests on the sludge material at the Geotechnical Laboratories, Trinity College Dublin. The paper was resubmitted while the author was on sabbatical leave at the Urban Institute Ireland, University College Dublin.

\section{References}

Aydilek, A.H., Edil, T.B., Fox, P.J., 2000. Consolidation characteristics of wastewater sludge. In: Edil, T.B., Fox, P.J. (Eds.), Geotechnics of High Water Content Materials, ASTM STP, 1374. American Society for Testing and Materials, pp. 309-323.

BS1377, 1990a. Methods of Test for Soils for Civil Engineering Purposes. Part 2: Classification tests. British Standards Institution, London.

BS1377, 1990b. Methods of Test for Soils for Civil Engineering Purposes. Part 3: Chemical and electro-chemical tests. British Standards Institution, London.

BS1377, 1990c. Methods of Test for Soils for Civil Engineering Purposes. Part 5: Compressibility, permeability and durability tests. British Standards Institution, London.

Casagrande, A., Fadum, R.E., 1940. Notes on soil testing for engineering purposes. Harvard University Graduate School of Engineering. Publication 8.

Cooling, L.F., Skempton, A.W., 1941. Some experiments on the consolidation of clay, Journal of Institution of Civil Engineers, 16, 381-398.

Klein, A., Sarsby, R.W., 2000. Problems in defining the geotechnical behaviour of wastewater sludges. In: Edil, T.B., Fox, P.J. (Eds.), Geotechnics of High Water Content Materials, ASTM STP, 1374. American Society for Testing and Materials, pp. 74-87.

Lambe, T.W., Whitman, R.V., 1969. Soil Mechanics. Wiley, New York.

Lo, I.M.C., Zhou, W.W., Lee, K.M., 2002. Geotechnical characterization of dewatered sewage sludge for landfill disposal, Canadian Geotechnical Journal, 39, 1139-1149.

Metcalf and Eddy, Inc., 1991. Wastewater Engineering: Treatment, Disposal and Reuse. McGraw-Hill, Singapore.

Mesri, G., Shahien, M., Feng, T.W., 1995. Compressibility parameters during primary consolidation. In: Proceedings, International Symposium on compression and consolidation of clayey soils, vol. 2, Hiroshima, pp. 1021-1037.

O'Kelly, B.C., 2005a. Consolidation properties of a dewatered municipal sewage sludge, Canadian Geotechnical Journal, 42, 1350-1358.

O'Kelly, B.C., 2005b. Mechanical properties of dewatered sewage sludge. Waste Management, 25, (1), 47-52.

O'Kelly, B.C., 2006. Geotechnical properties of municipal sewage sludge, Geotechnical and Geological Engineering, 24, (4), 833-850. 
Sarsby, R.W., 2005. Geotechnical properties of sewage sludge. In: Proceedings, International Conference on Soil Mechanics and Geotechnical Engineering, vol. 3, Osaka, pp. 2327-2329.

Stone, R.J., Ekwue, E.I., Clarke, R.O., 1998. Engineering properties of sewage sludge in Trinidad, Agricultural Engineering Research, 70, 221-230.

Taylor, D.W., 1942. Research on Consolidation Clays. Department of Civil and Sanitation Engineering. Massachusetts Institute of Technology, Report 82.

Terzaghi, K., 1943. Theoretical Soil Mechanics. Wiley, New York. 
Table 1. Properties of material tested direct from the treatment plant (specimen A)

\begin{tabular}{lc}
\hline Parameter & Value \\
\hline Water content (\%) & 705 \\
Solids content (\%) & 12 \\
Liquid limit (\%) & 315 \\
Plastic limit (\%) & 55 \\
Plasticity index (\%) & 260 \\
Particle size & 90 \\
$\quad$ (\% passing $425-\mu \mathrm{m}$ sieve) & \\
Specific gravity of solids & 1.55 \\
Total volatile solids (\%) & 70 \\
Linear shrinkage (\%) & 32 \\
Shrinkage limit (\%) & 10 \\
Bulk unit weight (tonne $\left./ \mathrm{m}^{3}\right)$ & 1.03 \\
Dry unit weight (tonne $\left./ \mathrm{m}^{3}\right)$ & 0.13 \\
Void ratio & 11 \\
pH & 8.0 \\
\hline
\end{tabular}

Table 2. Properties of material tested after storage for an additional 13-year period (specimens B-E)

\begin{tabular}{lc}
\hline Parameter & Value \\
\hline Water content $(\%)$ & 655 \\
Solids content $(\%)$ & 13 \\
Specific gravity of solids & 1.71 \\
Total volatile solids $(\%)$ & 55 \\
Bulk unit weight (tonne $\left./ \mathrm{m}^{3}\right)$ & 1.04 \\
Dry unit weight $\left(\right.$ tonne $\left./ \mathrm{m}^{3}\right)$ & 0.14 \\
Void ratio & 11 \\
\hline
\end{tabular}


Table 3. Set up for the oedometer tests on specimens A-E

\begin{tabular}{|c|c|c|c|c|c|c|}
\hline Specimen & $\begin{array}{c}\text { Degradation } \\
\text { level }\end{array}$ & $\begin{array}{c}\text { Initial } \\
\text { water } \\
\text { content } \\
(\%) \\
\end{array}$ & $\begin{array}{l}\text { Dimensions } \\
(\mathrm{mm})\end{array}$ & $\begin{array}{l}\text { Applied } \\
\text { stress } \\
(\mathrm{kPa}) \\
\end{array}$ & $\begin{array}{c}\text { Duration } \\
\text { load } \\
\text { stage } \\
\text { (days) }\end{array}$ & $\begin{array}{c}\text { Pore } \\
\text { pressure } \\
\text { measurement }\end{array}$ \\
\hline A & Moderate & 705 & $\begin{array}{l}76.2 \text { dia. } \times 30.0 \mathrm{H}^{\mathrm{a}}, \\
\text { two-way drainage }\end{array}$ & $\mathrm{MI}^{\mathrm{b}}: \sigma_{\mathrm{v}}^{\mathrm{c}}=3-100$ & 2 & No \\
\hline B & Strong & 655 & $\begin{array}{l}76.2 \text { dia. } x 30.0 \mathrm{H} \\
\text { two-way drainage }\end{array}$ & MI: $\sigma_{v}=3-100$ & 2 & No \\
\hline $\mathrm{C}$ & Strong & 655 & $\begin{array}{l}76.2 \text { dia. x } 14.8 \mathrm{H} \text {, } \\
\text { one-way drainage }\end{array}$ & $\mathrm{MI}: \sigma_{\mathrm{v}}=3-100$ & 2 & Yes \\
\hline $\mathrm{D}$ & Strong & 655 & $\begin{array}{l}76.2 \text { dia. } \times 30.0 \mathrm{H} \\
\text { two-way drainage }\end{array}$ & $\mathrm{SI}^{\mathrm{d}}: \sigma_{\mathrm{v}}=3$ & 9 & No \\
\hline $\mathrm{E}$ & Strong & 655 & $\begin{array}{l}76.2 \text { dia. x } 14.8 \mathrm{H} \text {, } \\
\text { one-way drainage }\end{array}$ & SI: $\sigma_{v}=6$ & 9 & Yes \\
\hline
\end{tabular}

${ }^{\mathrm{a}}$ specimen height.

${ }^{\mathrm{b}}$ multiple increment.

${ }^{\mathrm{c}}$ applied vertical stress.

$\mathrm{d}$ single increment.

Table 4. Secondary compression of material tested direct from the treatment plant (specimen A)

\begin{tabular}{cccc}
\hline $\begin{array}{c}\text { Applied } \\
\text { stress } \\
(\mathrm{kPa})\end{array}$ & $\mathrm{C}_{\mathrm{sec}}$ & $\mathrm{C}_{\alpha \mathrm{ee}}$ & $\mathrm{C}_{\alpha \mathrm{e}} / \mathrm{C}_{\mathrm{c}}$ \\
\hline 3 & 0.02 & 0.18 & - \\
6 & 0.04 & 0.47 & 0.12 \\
12.5 & 0.07 & 0.88 & 0.12 \\
25 & 0.10 & 1.13 & 0.20 \\
50 & 0.09 & 1.11 & 0.25 \\
100 & 0.07 & 0.77 & 0.18 \\
\hline
\end{tabular}


Table 5. Secondary compression of material that had degraded over an additional 13-year period

\begin{tabular}{ccccccc}
\hline \multirow{2}{*}{$\begin{array}{c}\text { Applied } \\
\text { stress }\end{array}$} & \multicolumn{3}{c}{ Specimen B } & \multicolumn{4}{c}{ Specimen C } \\
\cline { 2 - 7 }$(\mathrm{kPa})$ & $\mathrm{C}_{\mathrm{sec}}$ & $\mathrm{C}_{\alpha \mathrm{ce}}$ & $\mathrm{C}_{\alpha \mathrm{ee}} / \mathrm{C}_{\mathrm{c}}$ & $\mathrm{C}_{\mathrm{sec}}$ & $\mathrm{C}_{\alpha \mathrm{\alpha e}}$ & $\mathrm{C}_{\alpha \mathrm{e}} / \mathrm{C}_{\mathrm{c}}$ \\
\hline 3 & 0.17 & 2.18 & 0.43 & 0.20 & 2.41 & 0.47 \\
6 & 0.11 & 1.38 & 0.36 & 0.11 & 1.33 & 0.37 \\
12.5 & 0.07 & 0.87 & 0.23 & 0.07 & 0.77 & 0.22 \\
25 & 0.09 & 1.10 & 0.29 & 0.08 & 0.96 & 0.27 \\
50 & 0.06 & 0.73 & 0.23 & 0.05 & 0.57 & 0.20 \\
100 & 0.04 & 0.54 & 0.20 & 0.04 & 0.45 & 0.17 \\
\hline
\end{tabular}




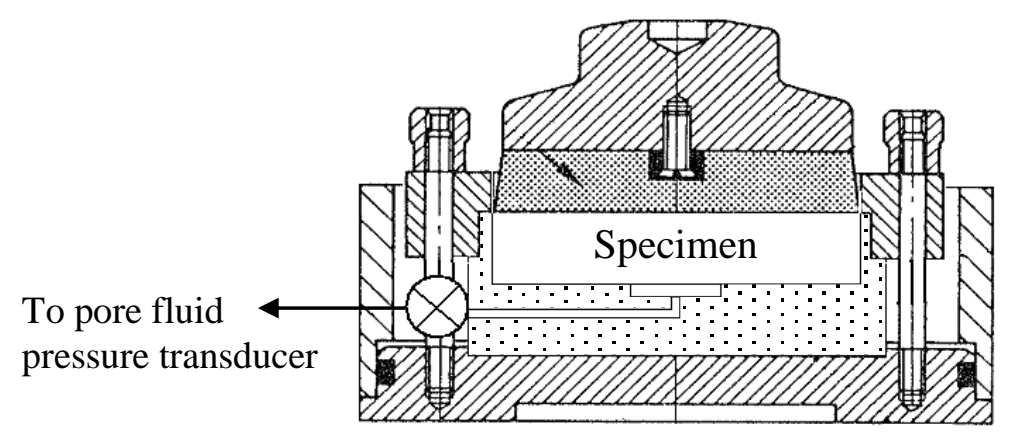

Fig. 1. Oedometer cell incorporating pore fluid pressure measurement for specimens $\mathrm{C}$ and $\mathrm{E}$.

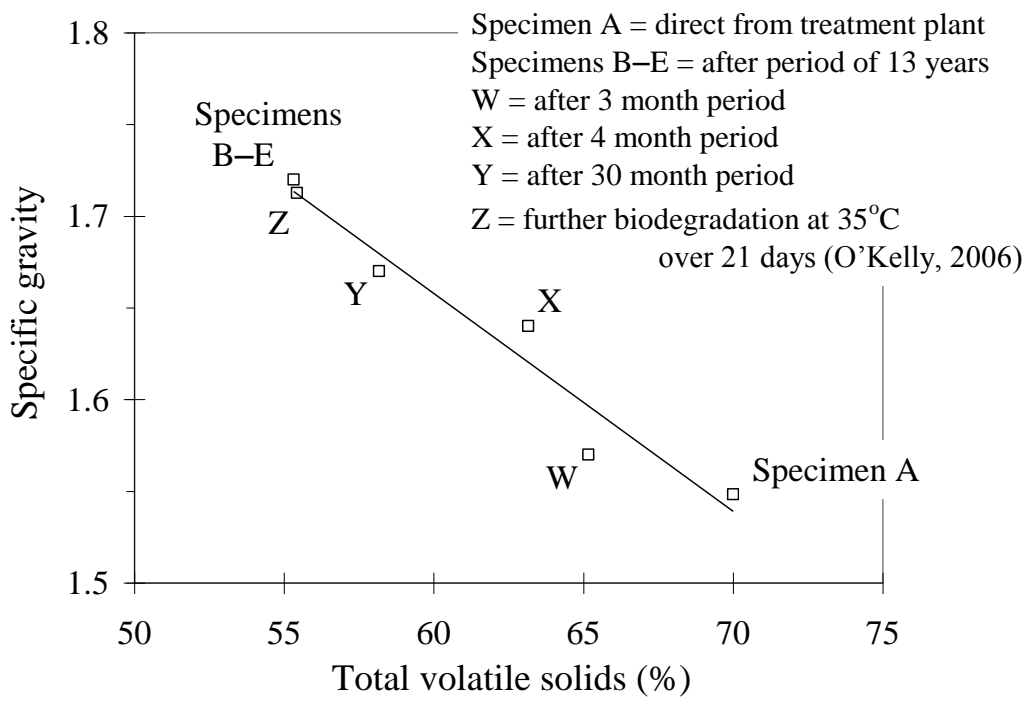

Fig. 2. Specific gravity versus TVS. 


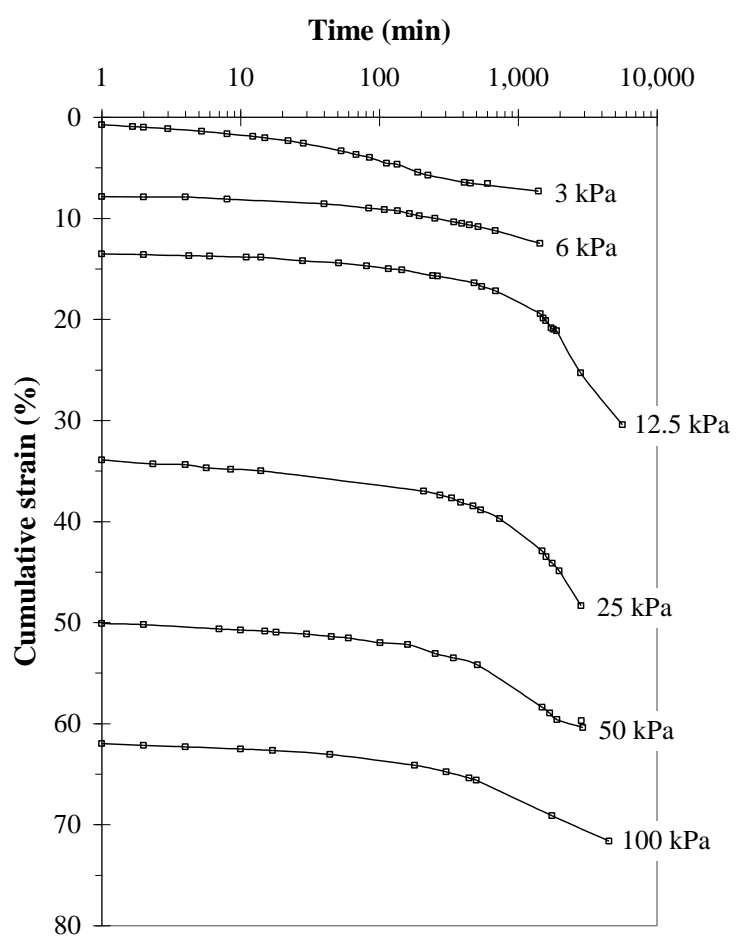

(a) Logarithm time.

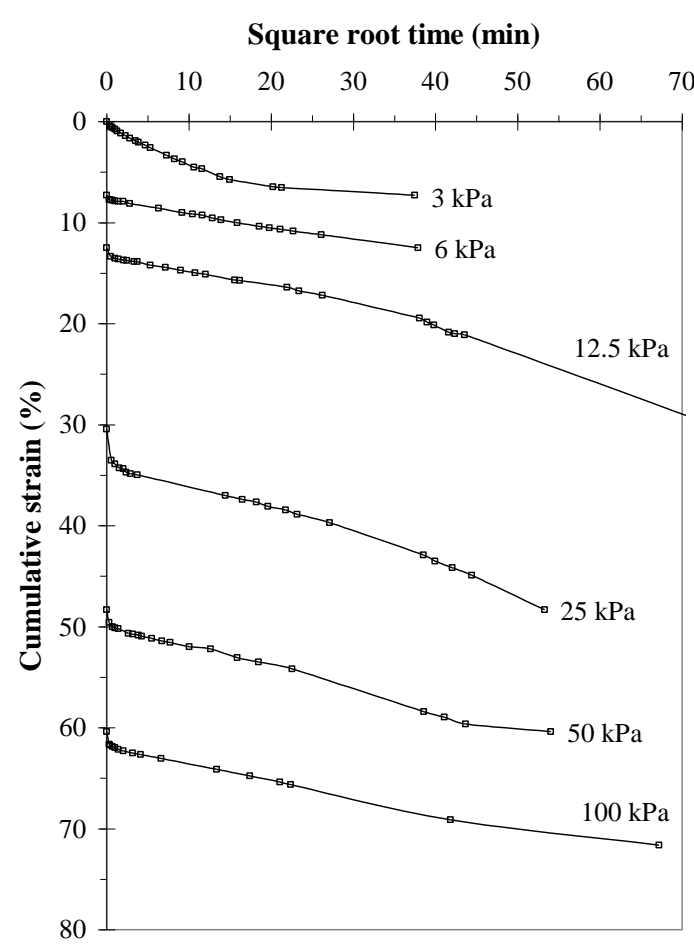

(b) Square-root time.

Fig. 3. Compressibility of material tested direct from the treatment plant (specimen A). 

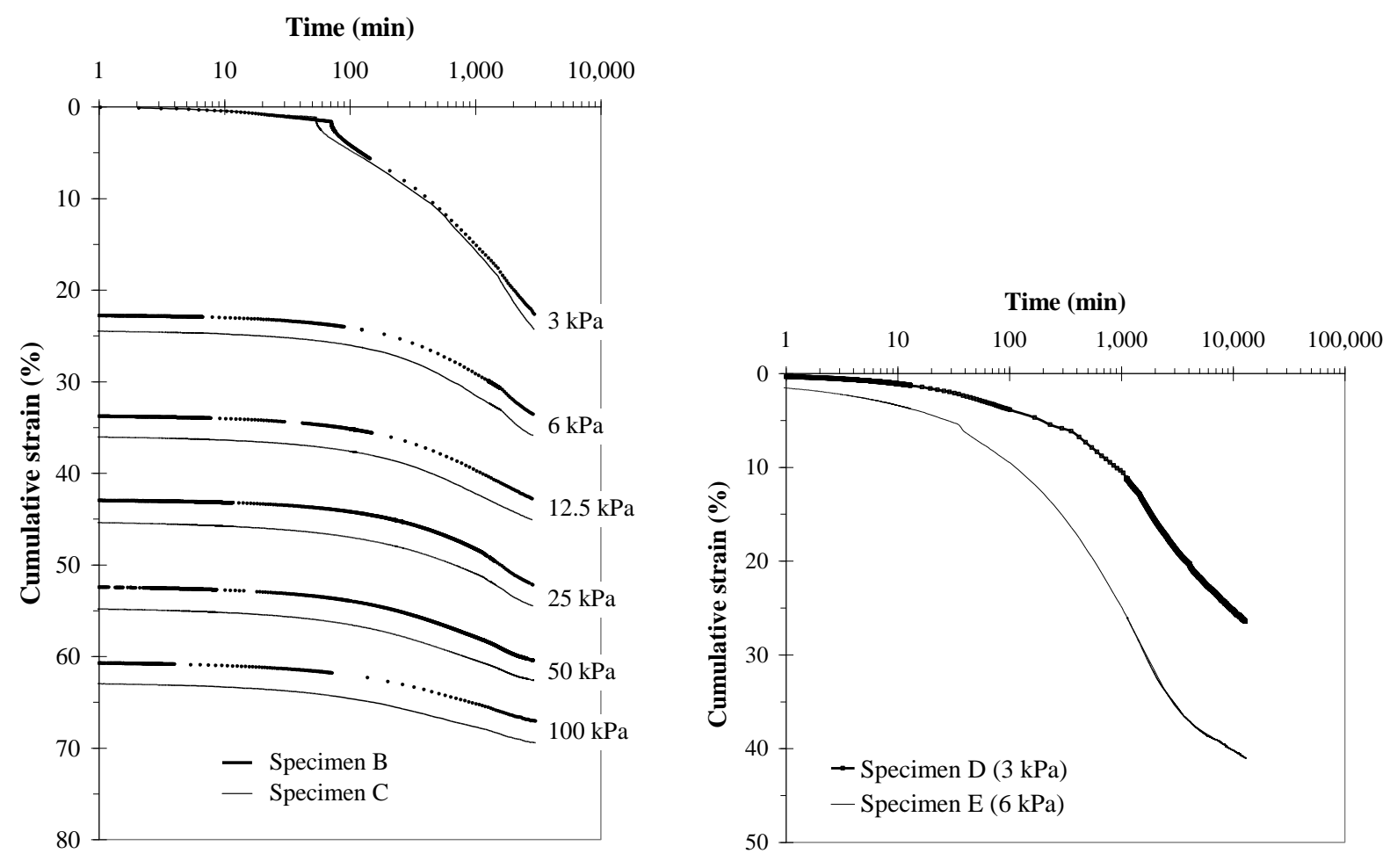

(a) Logarithm time.
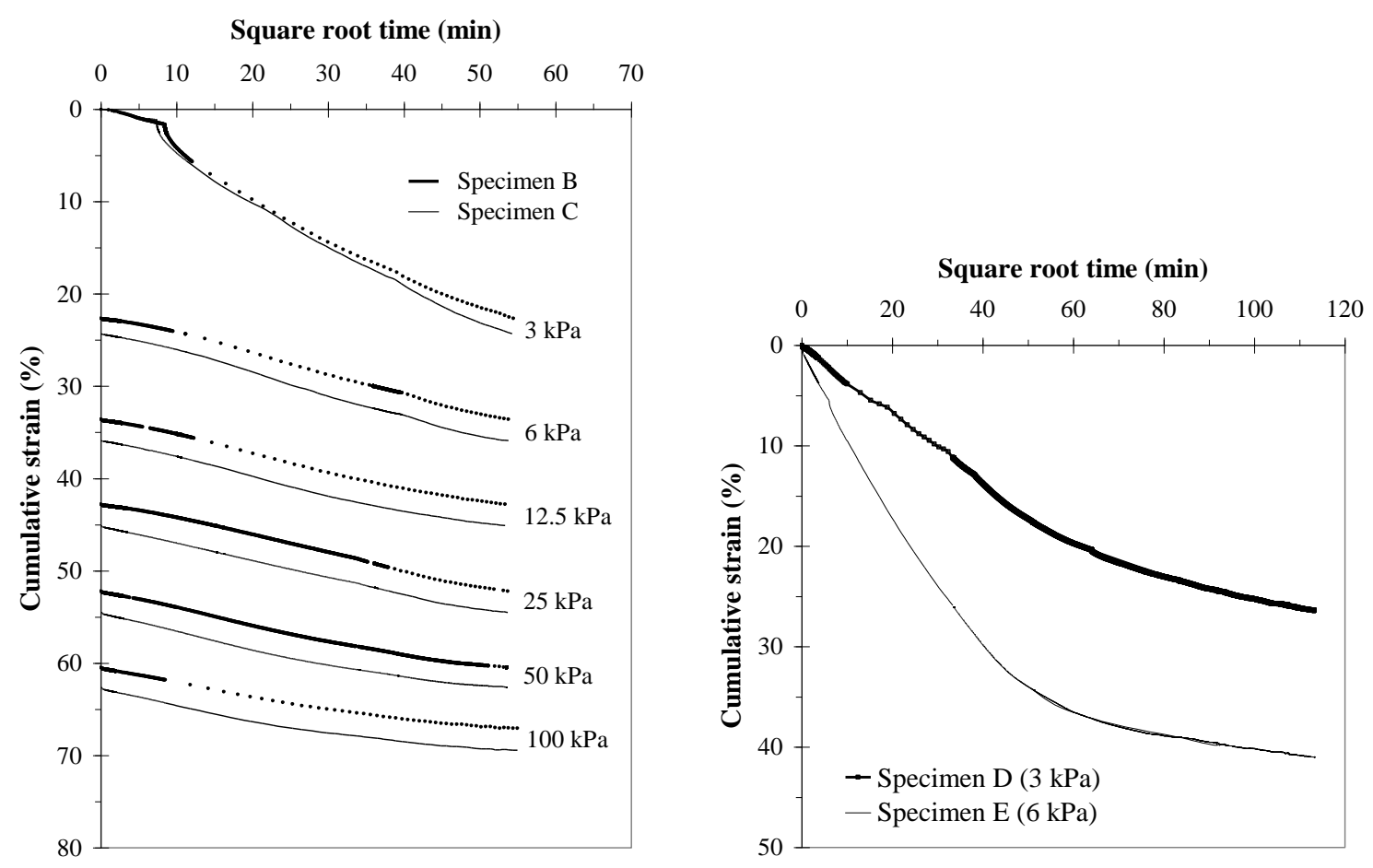

(b) Square-root time.

Fig. 4. Compressibility of material tested after 13-year storage period (specimens B-E). 


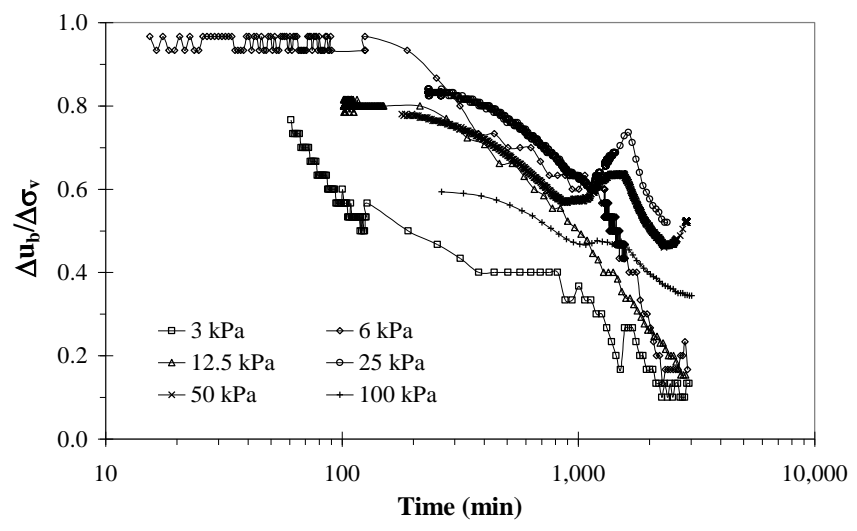

(a) Specimen C.

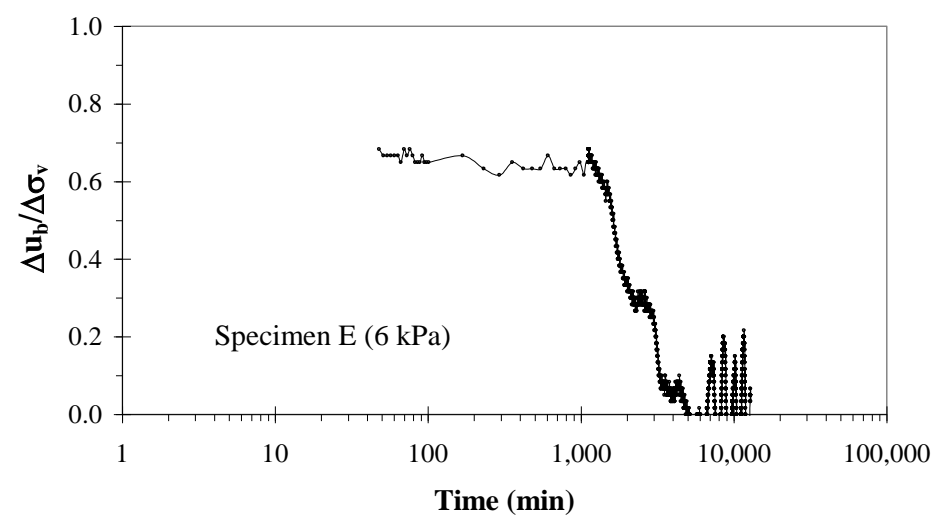

(b) Specimen E.

Fig. 5. Normalized excess pore fluid pressure responses. 


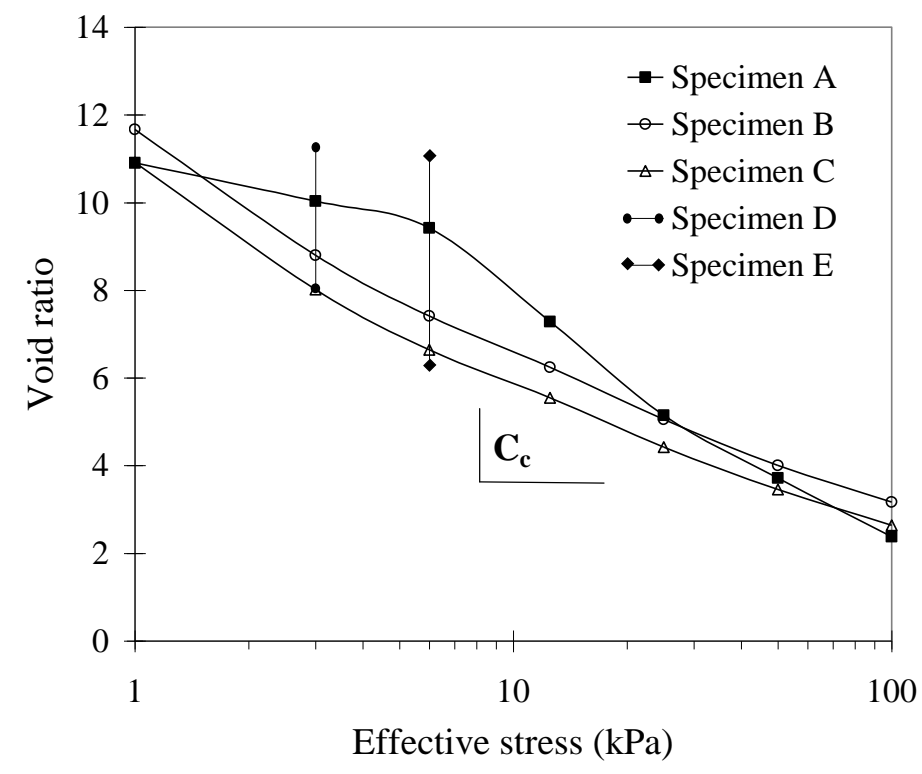

Fig. 6. Void ratio versus logarithm of effective stress. 


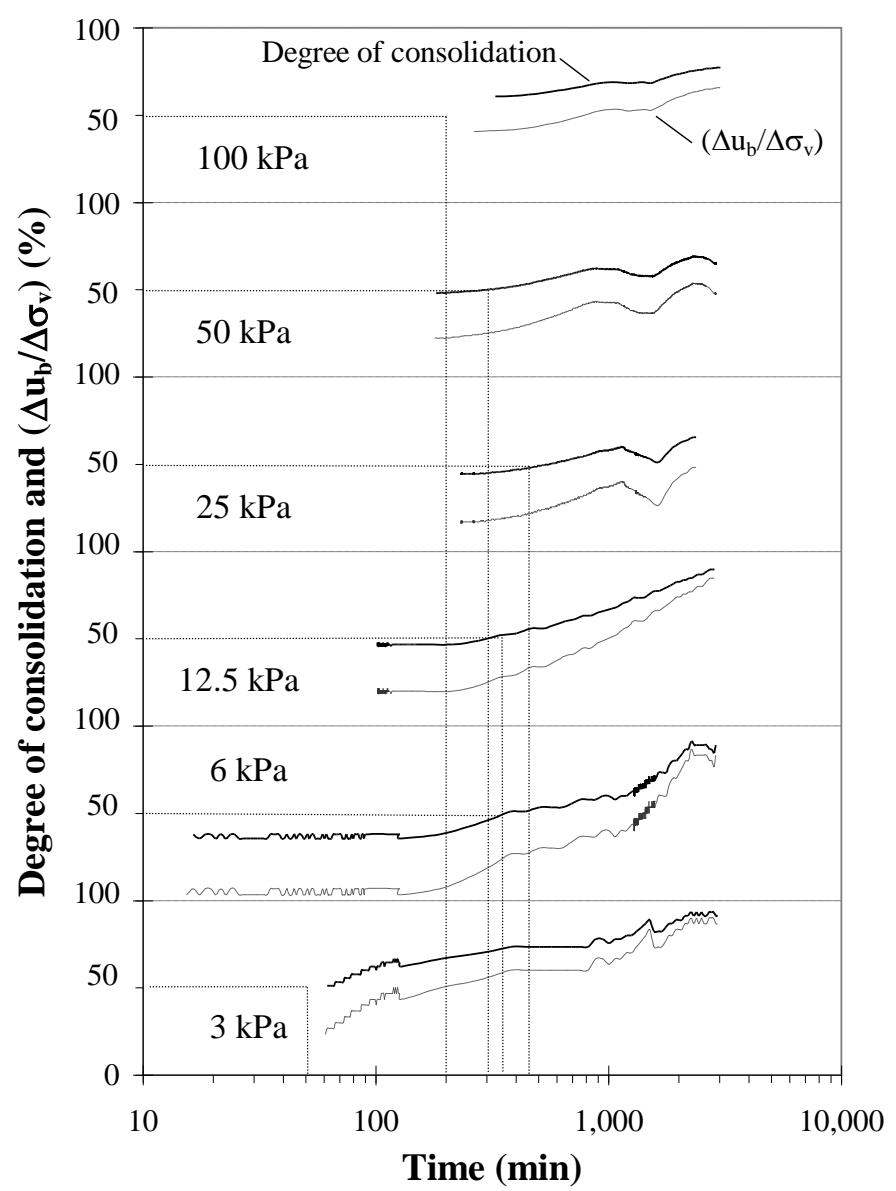

(a) Specimen C.

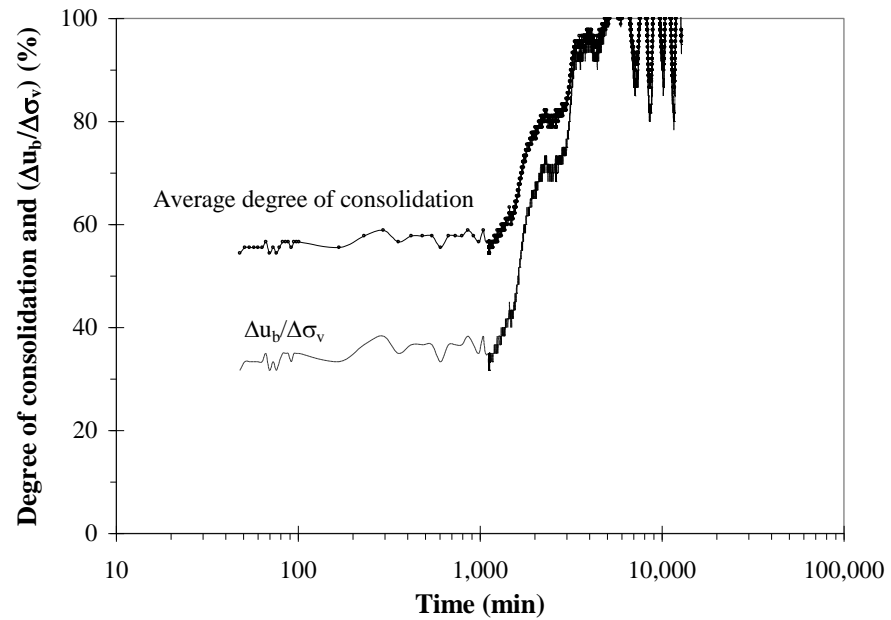

(b) Specimen E $\left(\sigma_{\mathrm{v}}=6 \mathrm{kPa}\right)$.

Fig. 7. Average degrees of consolidation achieved. 


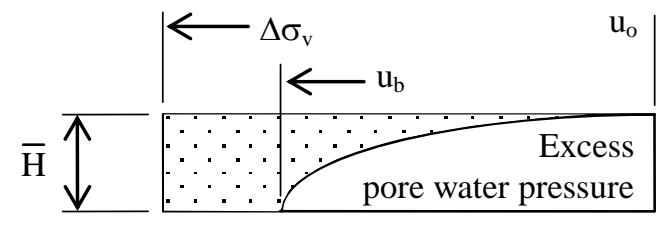

Fig. 8. Distribution of excess pore fluid pressures across the specimen height.

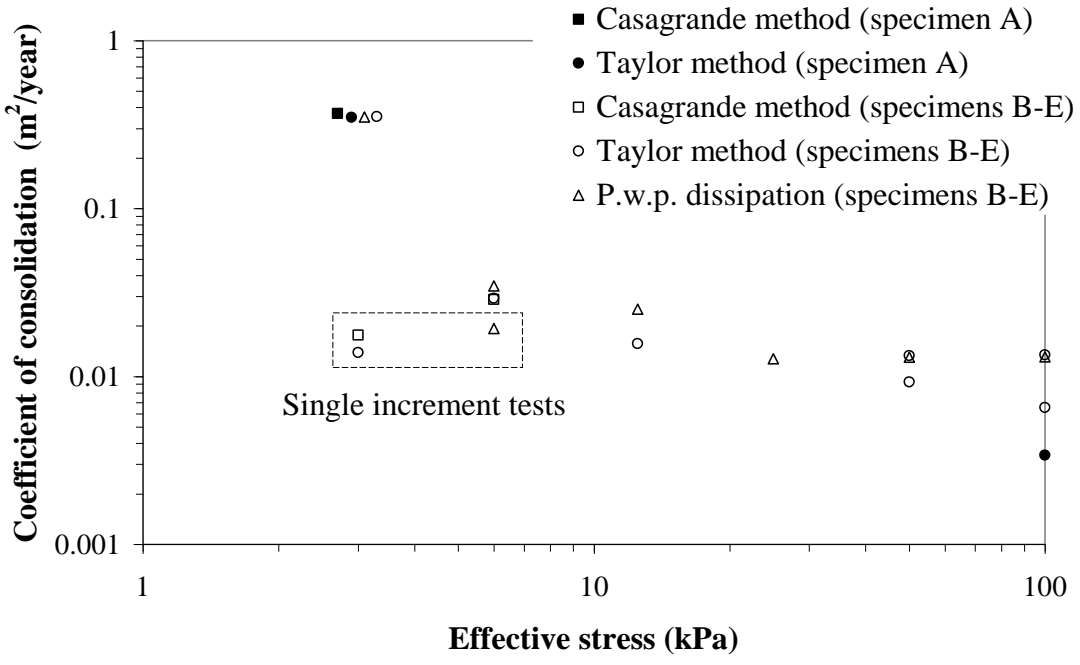

Fig. 9. Coefficient of consolidation versus effective stress. 
口 Casagrande method (specimens B-E)

- Taylor method (specimens B-E)

$\Delta$ P.w.p. dissipation (specimens B-E) - Water content (specimens B-E)

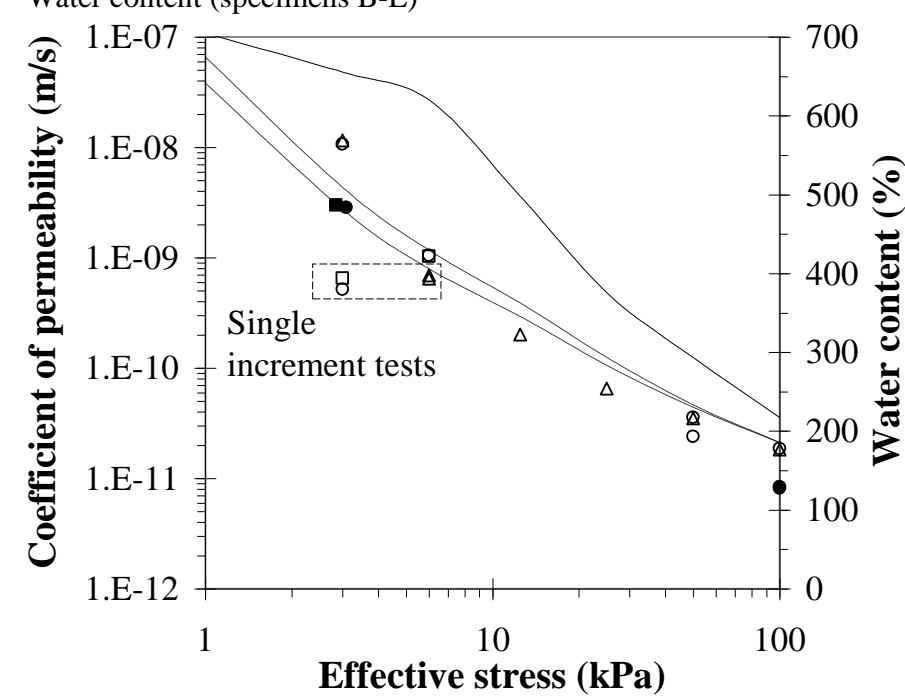

(a) versus effective stress

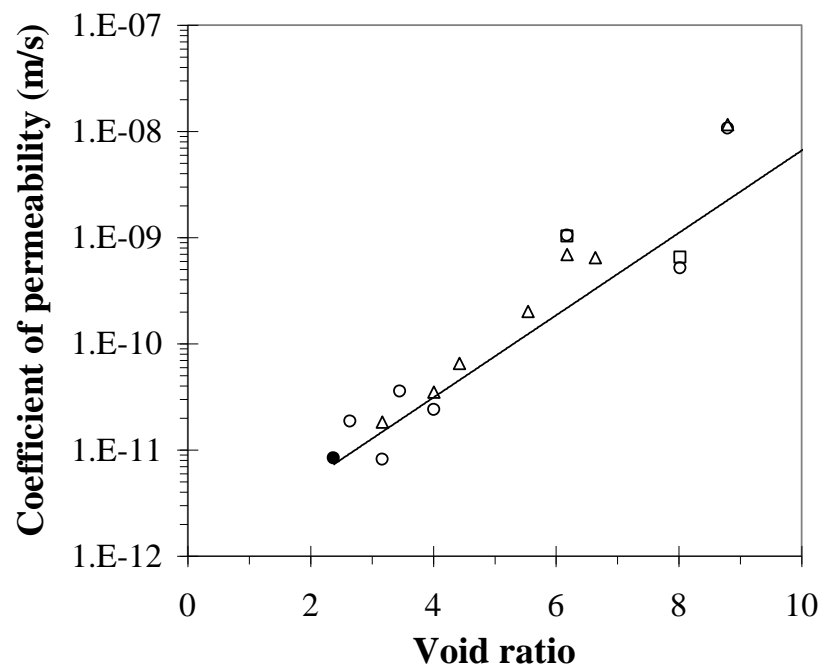

(b) versus void ratio.

Fig. 10. Coefficient of permeability relationships. 


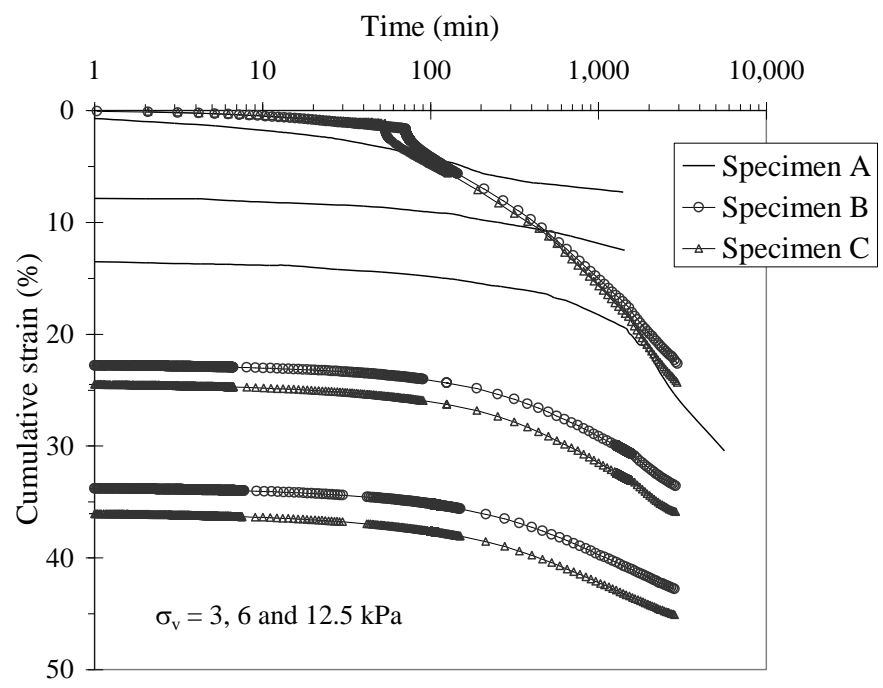

Fig. 11. Comparison of the strain responses for the sludge materials. 